\title{
Avrupa Basınındaki Görsel Metinlerde Kültürel Kodlar: Osmanlı İmparatorluğu'nda Etnik Milliyetçilik Ayrıştırması
}

\author{
Cultural Codes in Visual Texts of the European Press: Ethnic Nationalism in \\ the Dissolution of the Ottoman State
}

\author{
Nurgül BEKAR * \\ Nesli Tuğban YABAN **
}

\begin{abstract}
Öz: 1789 Fransız Devrimi sonrası milliyetçilik hareketlerinin dalga dalga tüm dünyaya yayılması siyasi olduğu kadar kültürel olarak da yeni bir ayrıştırmaya yol açmıştır. 19. yüzyılla birlikte milliyetçilik akımlarını başat aktör olarak kurgulandığı ancak özünde emperyalist politikaların yer aldığı ve ulus devletlerin kurulmaya başlandığı bu süreçte, basılı görsel metinlerin milliyetçiliğin yayılmasında etkisi yadsınamayacak kadar önemlidir. 18. ve 19. yüzyıl dünya siyasetine baktığımızda Avrupa, Rusya ve Osmanlı İmparatorluğu arasında keskin siyasi yargıların hayata geçtiği ve farklı etnik kimliklerin birbirlerine bakışını etkilediği görülmektedir. Bu bağlamda geçmişten günümüze kadar etkisini hiç kaybetmeden sürdüren ve insanları etkilemenin en bilinen yolu olan imgelerde kullanılan kültürel kodlar yoğun biçimde insan hayatını etkilemiş, ulusal kimliklerin kazanılmasında belirleyici bir etki yapmıştır. Bu çalışma anılan döneme ilişkin, Avrupa basınındaki görsel metinler üzerinden üretilen kültürel kodları kapsayan bir dizi seçki içermektedir. Böylece imparatorluk topraklarındaki milliyetçi eylemlerin ortaya çıkması, anlaşılması ve sonrasında görsel metinlerin ne kadar etkili olduğu; Avrupa'nın Osmanlı İmparatorluğu'na karşı olan tavrının etnik milliyetçilik hareketlerinin körüklenmesinde destekleyici bir ortam yarattığı ortaya konmuş olacaktır.
\end{abstract}

Anahtar sözcükler: Milliyetçilik, Kültürel Kod, Avrupa Basını, Osmanlı İmparatorluğu, Görsel Metin

Abstract: The nationalist movements following the 1789 French Revolution spread in waves all over the world and led to new cultural as well as political separation lines. In the $19^{\text {th }}$ century, nationalist movements were constructed as the main actor, when the imperialist policies were at the core and nation-states were being established; the influence of printed visual texts can be considered as being undeniably important. During the evaluation of world politics of the $18^{\text {th }}$ and $19^{\text {th }}$ centuries, it is clearly seen that sharp political judgments were realized between Europe, Russia and the Ottoman Empire and that different ethnic identities influenced the view taken of each other. In this context, the cultural codes employed for the images, which are known to be the most effective way of influencing people from the past to the present, have been influential on human life and had a decisive effect in the acquisition of national identities. This study investigates a series of cultural codes that were produced through visual texts in the European press. Thus, how effective these visual texts were for the emergence and understanding of nationalist actions in imperial lands and Europe's attitude towards the creation of a supportive environment for the incitement of ethnic nationalist movements in the Ottoman state are shown.

Keywords: Nationalism, Cultural Code, European Press, Ottoman State, Visual Text

* $\quad$ Dr. Öğr. Üyesi, Kastamonu Üniversitesi, İİBF, Uluslararası İlişkiler Bölümü, Kastamonu. nurgulbekar@kastamonu.edu.tr, https://orcid.org/0000-0002-6267-0160

** Dr. Öğr. Gör, Başkent Üniversitesi, İletişim Fakültesi, Halkla İlişkiler ve Tanıtım Bölümü, Ankara. nesli@baskent.edu.tr, https://orcid.org/0000-0002-2029-6481 


\section{Giriş}

19. yüzyıl başlarında özellikle büyük imparatorlukların sonunu hazırlayan milliyetçi düşünceler Osmanlı İmparatorluğu için de sarsıcı etkiler getirmiş, üç kıtaya yayılan Devlet-i Âliye'nin sonunu hazırlamada ekonomik sorunlar ve askeri yetersizlikler kadar yer kaplamıştır. 18. yüzyılın ortalarından itibaren çekine çekine başlatılan Batılılaşma süreci sonunda uluslaşmanın önü alınamadığ 1 gibi, yapılan reformlar sayesinde imparatorluğun sonu da gelmiştir (Aktar 2003, 77). Gazetelerin kuruluşu, telgrafın ve demiryollarının gelişmesi, limanların ve tarımsal üretim merkezlerinin birbirine bağlanması ile oluşan iletişim devrimi; Osmanlı İmparatorluğu'nda ortaya çıkan milliyetçilikleri şekillendiren yapısal, kültürel ve örgütsel unsurların arasındaki etkileşimi artırmıştır (Göçek 2003, 65). İletişimin yaygınlaşması sayesinde gerek Türk milliyetçiliği gerekse diğer etnik topluluklar ve kültürlerin uluslaşma sürecinde kimliklerini tanımlanmasında basın ve özellikle görsel metinler bu durumu desteklemiştir. Türk milliyetçiliğinin oluşumu ve gelişimi Türk kimliğinin imparatorluğun ana öğesi olmasından hareketle başka bir akademik araştırmanın öznesi olarak değerlendirilmekte ve bu yüzden çalışmanın konusunu diğer etnik unsurların uluslaşma sürecindeki kültürel kodlar ayrıştırması oluşturmaktadır.

19. yüzyılda söz konusu tüm bu gelişmelere bağlı olarak Avrupa, Rusya ve Osmanlı İmparatorluğu arasında keskin siyasi yargıların da hayata geçtiği görülmektedir. Bu yargıların oluşmasında Avrupa basınında yer alan milliyetçilik temelli kültürel kodlar ayrıştırması büyük önem taşımaktadır. Bu ayrıştırma Batı basınının günlük ve haftalık haber gazetelerinin yanı sıra yalnızca görsellerin ve illüstrasyonların yer aldığı, haftalık siyaset ve kültür-sanat yayınlarına da yansımış; geçmişten günümüze kadar etkisini hiç kaybetmeden sürdüren ve insanları etkilemenin en bilinen yolu olan imgelerde kullanılan kültürel kodlar yoğun biçimde insan hayatını etkilemiştir. Milliyetçiliğin diğer coğrafyalara yayılmasında gazetelerin rolü büyüktür. Basında özellikle görsellerle bu ayrıştırmanın desteklenmesi gerek milliyetçilik etkilerinin yayılmasını hızlandırmış gerekse Avrupa ve Rusya tarafından söz konusu halkların desteklenmesini kolaylaştırılmıştır.

Nitekim Amerikalı siyaset bilimci Benedict Anderson (1936-2015), 19. yüzyılda basının, milli dili geliştirme yoluyla millet (Çalışmada millet ve ulus kelimeleri ile milliyetçilik ve ulusçuluk kavramları aynı anlamda kullanılmıştır) oluşumundaki rolünü kapitalist sistemin bir ürünü olarak vurgulamış ve milletin oluşumunda döneme ait gazetelerin incelenmesinin milletin ne tür bir hayali cemaat olduğunu göstereceğini ifade etmiştir.

Çalışma kapsamında ilk olarak kavramsal ve teorik çerçeve içinde milliyetçiliğin doğuşu ve milliyetçilik teorisi temel tanımlar eşliğinde incelenecektir. Ardından etnik milliyetçilik ve kültürel kodlar ayrıştırmasının görsel metinler üzerinden ne anlama geldiği analiz edilecektir. Kültürel kodlar ayrıştırmasında Avrupa basınının rolü, görsel metinlerde bu ayrıştırmaya sağlanan katkı araştırılarak imparatorluk topraklarında etnik milliyetçiliğin yayılmasını neden ve nasıl kolaylaştırdığg ortaya konacaktır. Sonuç bölümünde ise etnik milliyetçiliklerin Osmanlı İmparatorluğu'nun sonunu hazırlamada Avrupa basınının kullandığı görsellerin ne derece etkili olduğu açıklanmaya çalışılacaktır.

\section{Millet ve Milliyetçilik Kavramları}

Milliyetçilik temel özne olarak her zaman 'millet'i ele almakta, milleti tanımlamaktadır (Çiller 2015, 50). Bir başka ifadeyle İngiliz tarihçi ve yazar Eric Hobsbawm (1917-2012)'un savunduğu gibi milletler devletleri ve milliyetçilikleri değil, milliyetçilikler milleti yaratmaktadır (Hobsbawm 1993, 24) Dolayısıyla milliyetçiliğini çıktısı olan milletin ne ifade ettiğini anlamak, milliyetçiliği anlamak için ilk adımı oluşturmaktadır.

Milliyetçilik ideolojisinin özü olan 'millet' yani 'natio' kavramı Kerestecioğlu'na (2012) göre, sözel olarak ilk kullanıldığı dilde (Latince) etimolojik açıdan olumsuz bir anlam içer- 
mektedir. Roma İmparatorluğu'nda aynı bölgeden gelen yabancıları anlatmak için kullanılan sözcük, 'natio' grubunun Roma yurttaşı olmadığını nitelemek ve bu topluluğun sosyal statülerinin kendilerinden aşağıda olduğunu belirtmek için kullanılmıştır. Sözcüğün yazılı olarak ilk kullanımı ise Arapça 'milla' kökeninden gelmektedir ve aynı dili konuşan veya bir/aynı dine mensup cemaat anlamlarını taşımaktadır. Ortaçağa gelindiğinde 'natio-n' sözcüğünün anlamı dönüşmüş ve üniversitelere gelen öğrenci grupları için kullanılmıştır. Böylece 'nation' sözcüğü yalnızca skolastik tartışmalarda ortak görüşler geliştirmeye başlayan öğrencilerin kökenini değil aynı zamanda topluluğun fikrini ve amacını da ifade etmeye başlamıştır. Üniversiteler, çeşitli dinsel sorular hakkında hüküm vermek üzere kilise konseylerine temsilciler gönderdikçe, kelime yeni bir dönüşüm geçirmiş, 13. yüzyıl sonlarında bir 'görüş topluluğu' anlamına gelmeye başlamıştır. İlk kez 16. yüzyıl İngiltere'sinde, eliti içeren anlamıyla birlikte ülke nüfusunu yani halk1 anlatmak için kullanılan sözcük, tıpkı halk kavramının bir bölgenin nüfusunu anlattığı gibi, sınıfsal bir anlama da sahip olmuştur. Böylece halk, ilk kez modern siyasetteki anlamına kavuşmuş; egemenliğin taşıyıcısı, siyasal dayanışmanın temeli, bağlılığın yüce nesnesi haline gelmiş ve egemenlik kullanan halk bundan sonra millet olarak anılmaya başlanmıştır (Kerestecioğlu 2012, 315-316).

Milletlerin ezeli ve ebedi varlıklar olmadıkları (Calhoun 2012, 43) görüşünden yola çıkarak milletin çok çeşitli tanımları yapılmıştır. Modern siyasetteki millet kavramına, modernleşme ekolünün izlerini taşıyan ve 'millet kurma' (nation-building) sürecine odaklanan alternatif çalışmalarda rastlanır. Kuramlarında kitlesel iletişimin yaygınlaşmasını ön plana çıkaran bu araştırmacıların en önemlisi hiç kuşkusuz Çek siyaset bilimci Karl W. Deutsch (1912-1992)'tur. Modernist yaklaşımın öncülerinden de olan Deutsch, millet kurmayı toplumsal-demografik süreçlere bağlar. Kentleşme, artan toplumsal hareketlilik ve okuma yazma oranları, gelişen iletişim teknolojisi milletlerin kurulmasını kolaylaştırır. Bu sürecin başarıya ulaşması toplumsal hareketlilik ve kültürel bütünleşmenin birbirini tamamlamasıyla mümkündür. Deutsch'un çizdiği tabloda kitle iletişim araçları önemli bir yere sahiptir. Bu süreçte topluma yeni bakış açıları sunma, bireyleri ortak ideallere inandırma görevi kitle iletişim araçları tarafindan yerine getirilmelidir (Özkırımlı 2013, 62). Deutsch'un bu yaklaşımı, aslında tarihler boyunca milletlerin milliyetçi olma yolunda yalnızca iletişim araçları ve yöntemleriyle değil; bayrak, mimari, fiziksel özellikler, giyim tarzları vb. tüm görsel metinlerle de yönlendirildiklerinin bir çıtısı veya göstergesidir.

Bir insan topluluğunun millet olabilmesi için kendi ortak tarihine ihtiyaç vardır. Ortak tarih topluluğa hem meşruiyet sağlamakta hem de kimin kendinden kimin diğerlerinden olduğunu göstermektedir. Bu bağlamda milli geçmişler anavatanı, hayali cemaati, mitleri, düşmanları, çekilen çileleri, verilen şehitleri ve geçmiş zaferleri içermekte ve açıklamaktadır (Suny 2001, 869-870). Anderson milletin sınırlı, egemen ve bir topluluk olarak hayal edildiğini çünkü her ulusta fiilen geçerli olan eşitsizlik ve sömürü ilişkileri ne olursa olsun ulus daima derin ve yatay bir yoldaşlık olarak tasarlandığını söylemiştir (Anderson 2011, 21-22). Hobsbawm da milleti devletle ilişkilendirerek milletin ne asli ne de değişmez bir toplumsal bir birim olduğunu belirtmiş̧ir (Hobsbawm 1993, 24). İngiliz sosyolog Anthony D. S. Smith (1939-2016) ise millet kavramını 'anavatan olarak kabul edilen yerde ikamet eden, ortak mitlere ve paylaşılan bir tarihe, farkl bir kültüre, tek bir ekonomiye, bütün üyeleri için ortak yasalara ve göreneklere sahip olan, adlandırılmış insan topluluğu' olarak tanımlamayı önermiştir (Smith 2013, 25). Millet/ulus üzerine yapılan tanımlamalara bakıldığında genel olarak dil, kültür ve tarih açısından bir ortaklık olmasına vurgu yapılmaktadır. Milletin işaret ettiği bir başka özellik ise, egemen halkın aynı zamanda 'biricik' olmasıdır. (Kerestecioğlu 2012, 316). Öyleyse milleti en kısa şekilde ortak bir kimliği paylaşan egemen insanlar topluluğu olarak tanımlamak yanlış olmayacaktır. 


\section{Milliyetçilik: Tarihsel Süreç ve Teori}

Milliyetçiliğin de millet gibi tek bir tanımı yoktur. Milliyetçilik 19. yüzyılın başında Avrupa'da icat edilmiş bir doktrindir (Kedourie 1994, 1). Yüzyıllar boyunca özellikle dinî, ideolojik ve siyasi anlamda baskı altında kalmış olan halklar 18. yüzyılda uyanışa geçmişler, 19. yüzyılla birlikte milliyetçilik düşüncesi çerçevesinde kurmak istedikleri ulus devletlerin hayata geçmesi ve hayatta kalması için kendi kararlarını almak konusunda girişimlerde bulunmaya başlamışlardır. Ancak söz konusu milliyetçilik duygusunun o dönemi ve sonrasını etkileyecek olumlu ve olumsuz yönleri bulunmaktadır. Olumlu yönü, bağımsız olma hakkı, yani halkların kendilerini ilgilendiren kararları alma hakkına sahip olmalarıdır ki bu süreçte yaşanan ayaklanmalara 'Halkların İlkbaharı' denilmektedir. Olumsuz yönü ise, bir halkın kendini komşularından daha üstün görmesine, daha üstün olduğunu açıklamasına ve buna dayanarak azınlıkların topraklarını kendi ülkesine katmasına yol açmıştır. Saldırgan ve savaşçı milliyetçilik, hem diğer ülkelerin bağımsızlığını hem de barışı tehdit eden bir tehlike olmuştur (Le Goff 1997, 64).

1789 sonrası tüm dünyaya yayılan milliyetçi fikirler önce milleti tanımlamış ve bu milletlere dair milliyetçilikleri üretmiş ve milliyetçiliği de devletle, bir başka ifadeyle iktidar gücüyle ilişkilendirmiştir. Milliyetçi ideoloji, devlet haline gelmeden önce de var olan bir ulus mitinden beslenmektedir ve ulusun meydana gelmesinde devletin her zaman belirleyici bir rolü olmuştur (Amin 2007, 234). Bu bağlamda milliyetçilik milletlerin kendi kaderini tayin hakkını ve bu noktadan hareketle kendi devleti olması gerektiğini savunmuş, devlet yönetimine geniş katılımla milliyetçiliğin güçlü kalacağını iddia etmiştir. Bu süreçte milliyetçilik bağlamında ön plana çıkan 'din' de Batı'nın üstün ve başkalarına egemen olmaya başladığı noktaya dikkati çekmek ve özellikle Hristiyanlığın özgünlügünü yüceltmek ve onu özel ve eşsiz niteliklerle bezemek için kullanılmıştır (Amin 2007, 122).

Napolyon'un, Avrupa kıtası üzerinde hâkimiyetini savaşlarla sağlaması kadar 'Din olmadan bir devlette siyasi düzen devam ettirilemez' prensibinin sonucu olarak 1801'den sonra Papa ile dostluğunu kuvvetlendirmesinin de önemli payı vardır. Hristiyanlık dini çatısı altında toplanan Avrupa devletleri, Katolikliği imtiyazlı bir din mezhebi haline getiren Napolyon'a ve dolay1sıyla Fransa'ya büyük bir itibar kazandırmıştır (Kürkçüer 1969, 23). Fransız Devrimi sonrasında yaşanan savaşlar ve koalisyonlar, Napolyon'un Avrupa'da bir üstünlük ve egemenlik kurmasına neden olduğu kadar, diğer Avrupa milletleri üzerinde ciddi ölçüde bir tepki oluşturmuştur. Devrimin hürriyet fikrini kullanarak kitlelerin hükümdarlara karşı ayaklanmasını sağlayan Napolyon'un, bu kitleleri kendi esareti altına alması, Avrupa'da milliyetçi duyguların ön plana çıkmasına neden olmuş, tek bir ülkede yaşanan devrim, bir anda tüm Avrupa'da fenomen haline gelmiştir (Halperin 2003, 123).

İlk olarak İspanya tarafından başlatılan milliyetçilik akımı, Almanya ve İtalya'da da kendisini göstermiş, 1789 Fransız Devrimi'nin doğrudan sonucu olan liberal ve milliyetçi düşünceler, Napolyon'un diğer Avrupa devletleriyle savaşları ve işgalleri ile hemen hemen tüm Avrupa'ya taşınmıştır (Sander 2003, 183). Ancak, Napolyon'un İtalya ve Almanya gibi ülkelerdeki küçük devletleri bir araya getirerek daha büyük krallıklar haline getirmesi, onları dağınık bir yapıda olmaktan kurtarmıştır. Bu niteliklerinden dolayı, söz konusu ülkelerin milli birliklerini sağlama süreçleri hızlanmıştır (Armaoğlu 1973, 27).

Fransız Devrimi'ni izleyen yıllarda Napolyon'un önderliğinde yapılan savaşlar, anlaşmalar ve koalisyon çalışmaları, Napolyon'un Moskova Seferi'nden yenilgiyle ayrılması sonucu farklı bir boyut kazanmıştır. Kendi ülkesi Fransa da dâhil olmak üzere Avrupa milletleri, Rusya'dan ağır bir yenilgi ile dönen Napolyon'a karşı ayaklanmışlardır. Tüm bu yaşananlar, Napolyon'un siyasi iktidarını sonlandırmış, ardından Avrupa milletlerinin yapılanması ve yeni bir Avrupa haritası oluşturulması için Viyana Kongresi'nin toplanmasına karar verilmiştir. Viyana Kongresi, Napolyon'a karşı savaşmak için her zaman iletişim halinde olan Avrupa devletlerinin, 
Napolyon İmparatorluğu'nun yıkılmasıyla Avrupa'da meydana gelen boşluğu, kendi çıkarlarına uygun bir şekilde doldurmak için bir araya geldiği bir siyasi birlikteliktir. Armaoğlu'na (1973) göre, Napolyon'un varlığı Avrupa devletlerini birleştirmiş, yokluğu ise birbirine düşürmüştür. Gerçek anlamda bir Avrupa'nın oluşumu ise Fransa ve Avusturya-Macaristan devletlerinin yaşanan savaşlar ve ayaklanmalar sonucunda diğer Avrupa devletleri üzerindeki etkisinin ve kontrolünün ortadan kalkmasıyla gerçekleşecektir (Shaw \& Shaw 1977, 146).

Avrupa'da yaşanan tüm bu dönüşümler, yalnızca devletlerin siyasi birliklerinin sağlanması ya da sınırlarının belirlenmesi aşamasında değil, yeni yönetim biçimlerinin benimsenerek uygulamaya geçirilmesi aşamalarında, ekonomik-toplumsal yaşam ve sınıfsal yapılar üzerinde de etkili olmuştur. Avrupa kıtasında 1789 Fransız Devrimi'nden önce, yalnızca İngiltere'de parlamenter rejim bulunurken, 19. yüzyıl içinde çok sayıda Avrupa ülkesi bu sisteme idarelerinde yer vermiş, medeni ve siyasal haklar da ancak bu tarihlerden sonra yerleşmeye ve dönüşmeye başlamıştır (Kürkçüer 1969, 3). 19. yüzyıl Avrupa'da parlamentolar çağıdır. Avrupa Savaşları’nın sonucu ise, mutlakiyetçiliğin mağlubiyeti, liberalizm zaferi, milliyetçiliğin ise önemli ölçüde yol alması olarak değerlendirilebilir. 19. yüzyılın ikinci yarısından itibaren ise uluslararası dönüşümler, halkların artan özsaygıları ve artan özgürlük çağrıları hız kazanmıştır (Schmidt 1992, 53).

Hem kültürel hem de siyasi bir olgu olan ve gücünü bu olgudan alan milliyetçilik daha önceden var olan kimlik ve geleneklerden kaynağını alır, ulusal kimlikler de bu gelenekleri yansıtır (Özkırımlı 2010, 20, 27). Dolayısıyla ulusal kimliklerin oluşmasında ortak kültürlerin varlığ1 milliyetçiliğin temel söylemlerini biçimlendirmektedir. Bu söylemlerin ortak paydaları paylaşan topluklara ulaşması özellikle 19. yüzyıl başından itibaren okuma-yazma oranının artmasıyla daha da kolaylaşmıştır. Gazetelerin de desteğiyle kültürel ve tarihi benzerliklerin yakalanması, buna bağlı olarak devlet oluşumunda ve bağımsızlık hareketlerinde, ulusla devlet arasında tatminkâr bir anlaşma çabasını zorlamıştır (Calhoun 2012, 172).

\section{Etnisite ve Etnik Milliyetçilik}

Etnik milliyetçilik etnisitelerden bir millet yaratma ve o millete ait bağımsız bir devlete sahip olma iddiasını ortaya koymaktadır. Öyleyse etnisitenin tam olarak ne anlama geldiği burada önem kazanmaktadır. İlk olarak Amerikalı sosyolog David Riesman tarafindan kullanılan 'etnik' kelimesi çok daha eskilerden Yunanca 'ethnos’tan gelmektedir (Eriksen 2002, 15). 14. yüzyılın ortasından itibaren esasen ortak ırk özelliklerine, bir başka ifadeyle doğuştan gelen özelliklere sahip olmayı kasteden etnisite terimi belirli kültürel benzerlikleri taşıyan insan gruplarını anlatmaktadır. Bu çerçevede bireyin millete bağlılığı bir seçim değil, doğuştan gelen özellikleri nedeniyle kan bağı ile edindiği kendisine kalan mirastır ve dolayısıyla millete üyelik bir irade meselesi değildir (Özkırımlı 2010, 22). Etnisitelerin doğuştan sahip oldukları özellikler kadar, kendi dışındaki etnisiteler üzerinden yapacakları tanımlama da milletin oluşumuna etki edecektir. Etnik grubu belirleyen, zayıf ve sınırlı bölgesel bir ilişki, değişmez kültürel ortaklıklar, ortak bir kökene duyulan inançla şekillenmiş 'biz' bilinci, aktarılmış tarihsel anılar, etnikmerkezciliğe kadar varabilen belirgin bir üstünlük bilinci ve belli başlı efsanevi ya da tarihi kişilerin yanı sıra kültürel olguların da saygıdeğer semboller olarak umumiyetle tanınmasıdır (Breuer 2010, 29).

Milliyetçilik sayesinde etnisite daha farklı bir toplumsal kimliğe dönüştürülür, zaten etnisitenin kendisi de çoğu kolektif kimliğin geçmişteki örgütleniş biçiminin yalnızca bir cephesidir (Calhoun 2012, 52). Milliyetçiliğin bir millet yaratma çabası bağlamında milliyetçilik önceden var olan etnik kimliklerde temel değişiklikler yaparak kültürel miraslara yeni anlamlar katmakta, onları bir millet haline getirmeye, dönüştürmeye çalışmaktadır. Doğuştan sahip olunan din, dil ve kültüre ait unsurlar yazıya ve görsele döküldügünde yeni anlamlar kazanarak millet olmayı desteklemektedir. Etnisitenin millete dönüştürülme girişiminde devlet kavramı da önemli bir rol oynamaktadır, zira devlete sahip olma ve devlet üzerinde egemenlik iddia etme 
durumuyla etnisite artık bir millete dönüşecek, böylece dil-din, aile, sınıf gibi diğer kimlikleri de kapsayan daha üst bir yaşam alanı teşkil edilmiş olacaktır. Milliyetçilik etnik sınırların siyasi sınırlarla kesişmemesini gerektiren bir siyasi meşrulaştırma teorisidir ve 'ulusal birim' ile bir etnik grubu aynı anlama gelmektedir (Gellner 1983, 1). Bu da etnisitenin milliyetçi söylemin temel unsurlarından biri olduğunu ortaya koymaktadır.

Büyük devletler ve imparatorluklar içinde kalan etnisiteler 1789 Fransız Devrimi sonrasında yazılı ve görsel basının da etkisiyle milliyetçilik akımlarından etkilenmişlerdir. Hobsbawm (1993), 1870-1918 arasındaki milliyetçilik düşüncesini yüzyılın ilk yarısındaki milliyetçilikten ayırırken etnisitenin milliyetçiliğin ilk ortaya çıkışında merkezi öneme sahip değilken daha sonraları 'millet' olmadaki öneminin altını çizmektedir. Osmanlı İmparatorluğu'nda da 3 Kasım 1839'da imzalanan Tanzimat Fermanı (Gülhane Hatt-1 Hümâyûnu) ile etnisitelerin önemi artmış, bu tarihten itibaren Batı'nın baskısıyla etnisiteler daha fazla hak ve ayrıcalık talep etmiştir. Tanzimat Fermanı'nın arkasından gelen 28 Şubat 1856 tarihli Islahat Fermanı ile 1876 tarihli I. Meşrutiyet, Osmanlı İmparatorluğu'nu Batı tarzı bir anayasaya kavuştursa da etnisitelerin gittikçe milliyetçilik yönünde bilinçlenmeleri sonucunda dünya sahnesine yeni ulus devletler çıkmıştır. Zira iletişim araçlarının gelişmesi bu dönemde Osmanlı İmparatorluğu'na yansımış, hatta 1860'larda gazete, vilayet merkezlerinde vatandaşlar arasında birlik kurmak üzere devlet tarafından kullanılmıştır (Mardin 1994, 96). Bu bağlamda imparatorluğun dağılmasını engellemek için atılan adımların paradoksal bir biçimde tam tersi sonuç doğurduğunu söylemek yanlış olmayacaktır.

\section{Osmanlı İmparatorluğu'nda Millet Sistemi ve Etnik Milliyetçilik}

Osmanlı İmparatorluğu, farklı karakterlerdeki iki imparatorluğun ardılı sayılmaktadır: Bizans İmparatorluğu ve Selçuklu İmparatorluğu. 'Haç' ve 'Hilal' adına uzun süredir ihtilafa düşmüş olan bu iki imparatorluk, birbirini tüketerek sona ermiş, ardından gelen yeni devlet her bakımdan bir uzlaşmayı ifade etmiştir. Osmanlı İmparatorluğu Selçuklulardan İslam dünyasındaki liderliğini, Bizanslılardan da kendisine miras kalan tüm Hristiyan topraklarını devralmıştır (Belge 1939, 745). Osmanlı İmparatorluğu'nun altı yüz yıllık varlığının temelinde de bu kozmopolit yapının sürekliliği yatmaktadır.

Osmanlı İmparatorluğu, yayıldığı geniş coğrafi alanlardan çeşitli (sosyal, kültürel, siyasi ve ekonomik) etkiler almakla beraber, imparatorluk devrinde, kökü esas itibariyle Türk ve İslam kaynaklarına dayanan bir Osmanlılık düzeni ve bu düzen içinde şekillenen bir Osmanlı/Türk medeniyeti meydana getirmiştir (Cezar 1971, 1). Söz konusu bu yapılanma, imparatorluğa ancak 16. yüzyılın sonlarına kadar bir yükseliş sağlamış, 16. yüzyılın sonlarından itibaren bir duraklama ve gerileme dönemine girilmiştir. 16. yüzyıl sonları ile 17. yüzyıldan itibaren hızlanan bu süreç, Osmanlı İmparatorluğu'nun Balkanlar'daki ve Kafkaslardaki toprak ve güç kayıpları ile I. Dünya Savaşı'na kadar sürmüş, bu süreçte devlet yapısı da her geçen gün daha zayıf hale gelmiştir. Buna rağmen yine de Osmanlı İmparatorluğu, modernleşmenin anlamını kavrayan ilk ülkelerden biri olmuştur.

Osmanlı İmparatorluğu'nda 'millet' kavramı din, mezhep, bir din ve mezhebe bağlı topluluk anlamlarına gelmektedir (Eryılmaz 1990, 17). İmparatorluk Türk, Ermeni, Arap, Kürt, Yunan, Bulgar, Arnavut, Karadağlı, Bosnalı, Hırvat, Çerkez, Afrikalı, Lezgi vb. çok sayıda millet ve etnik kimlikten gelen farklı bir nüfus yapısına sahiptir. Osmanlı İmparatorluğu topraklarında Din, dinî toplulukların bağlı olduğu 'milletler sistemi' ile Müslüman olmayan grupların özel ve kamu hukuku alanındaki meselelerin halli gerçekleşebilmiştir. Millet sisteminin bir başka fonksiyonu ise gayrimüslimlerin ekonomik ve siyasi sisteme katılımlarını sağlamaktır (Güler 2000, 13). Şüphesiz bu ekonomik ve siyasi sistemden kaynaklanan büyüme ve zenginleşme hırslarından en çok etkilenecek ülkelerin başında, sahip olduğu geniş toprakların sömürgeleştirilmeye uygunluğu açısından Osmanlı İmparatorluğu gelmektedir. 
Söz konusu dönemde askeri üstünlüğün kaybedilmesi ve teknik alandaki gerileme imparatorluğun siyasal ve toplumsal yapısını da kaçınılmaz olarak etkilediğinden (Uçar 2018, 83), gayrimüslimler arasında milliyetçilik hareketleri yaygınlaşmıştır. Sıcak denizlere inmenin tek yolu olarak boğazları gören Rusya, bu amacı doğrultusunda Balkanlar üzerinden harekete geçmiş ve bölgede Slav-Ortodoks birliğini (Panslavizm) kurmak için bu halkların temsilcisi ve destekçisi rolünü üstlenmiştir. Birçok tarihçi, Karageorgeviç (1768-1817) liderliğindeki Sirp isyanının ilk milliyetçi ayaklanma olduğu konusunda hemfikirdir (Karpat 2014, 37). Sırp ayaklanmasına daha sonra Balkanlardaki diğer halkların ayaklanmaları da eşlik etmiş, bunların sonucunda Osmanlı İmparatorluğu'ndan ayrılan etnik kimliklerin kurduğu yeni devletler ortaya çıkmıştır.

Milliyetçilik ideolojisinin benimsendiği ve ulus devlet olma yolunda girişimlerde bulunulduğu bu dönemde Rusya'nın Balkanlar'da çıkarılan isyanları desteklemesi ve bu isyanların yayılması, Osmanlı İmparatorluğu'nun içinde bulunduğu sıkıntılar da göz önünde bulundurulduğunda zamanlama açısından çok anlamlıdır. Osmanlı İmparatorluğu, 1876 yılında Balkanlar'da, bölgede çıkan isyanların Balkan halkları birliği ideolojisi çerçevesinde büyümesi neticesinde bağımsız Bulgaristan'1 ilan edebilmek için mücadele eden Sırbistan ve Karadağ Prenslikleri ile çok sayıda cephede savaşmıştır. Bu savaşlar, Balkanlar sorununa siyasi bir çözümle yaklaşmak yerine isyanları şiddetle bastırma yoluna giden Osmanlı İmparatorluğu için başarıyla sonuçlanmasına rağmen, etnik milliyetçilik hareketleri açısından cesaret verici olmuştur.

Osmanlı İmparatorluğu'nda Tanzimat döneminden itibaren bazı haklar isteyen ve bu hakların bir kısmının Berlin Kongresi'nde kendilerine verileceği taahhüt edilmesine rağmen düzenleme kapsamının yetersiz olduğunu bahane eden Ermeniler, bağımsız Ermenistan'ı kurmak için silahlı komiteler kurarak ayaklanma hareketlerine girişmişlerdir. Ermeni isyanları ve 1885 'de Doğu Rumeli'nin Bulgaristan'a ilhakı, Girit'te yaşayan Rum halkı da hareketlendirmiş, Yunanistan'ın da desteğiyle Hanya kentinde Hristiyan ve Müslüman halk arasında çıkan çatışmalar 1897 Osmanlı-Yunanistan Savaşı'nın başlamasına zemin oluşturmuştur. Savaşa girmemek için uzlaştırıcı bir tutum takınan Osmanlı yönetimine karşın saldırgan bir tutum sergileyen Yunan yönetimi Hanya ve Kandiye'de çok sayıda Müslümanı öldürüp, 1897 yılında Girit'i Yunanistan'a ilhak ettiğini ilan etmiştir. Türk-Yunan sınırlarında yaşanan olumsuzluklar da duruma dâhil olunca yaklaşık bir yıl sürecek olan savaş başlamıştır.

Etnik toplulukların millet olma iddialarını uzun süre milletler sistemi ile bertaraf edebilen Osmanlı İmparatorluğu milliyetçilik dalgasının, imparatorluğun dağılma sebeplerinden birisi olmasını engelleyememiştir. 19. yüzyıl boyunca sınırları içerisinde ulus-devlet fikrinin ve etnik milliyetçi hareketlerin güçlenmesi ve buna bağlı olarak uluslaşma sürecinin hızlanmasıyla milliyetçiliğin doğal bir sonucu olarak imparatorluk yıkılmıştır.

Osmanlı İmparatorluğu'nda milliyetçiliğin yükselişi ve ardından otuz kadar ulus devletin kurulmasının ardında din, dinî gruplar veya milletler arasında rekabete dayanan ve ihtilaf yaratan ilişkiler, imparatorluğun siyasal yapısında gerçekleşen ilerici reform, aydınlanma felsefesi ve ideallerinin etkisi ve son olarak Rusya, Fransa ve İngiltere gibi ülkelerin emperyal çıkarları etkili olmuştur (Karpat 2014, 35). Tüm bu faktörlerin Osmanlı İmparatorluğu'na ulaşmasında ise Avrupa basını -özellikle görsellerle desteklediği tutumuyla- en önemli araçlardan birini teşkil etmektedir.

\section{Yüzyılda Avrupa Basını}

Batı dünyası olarak nitelenen Avrupa kıtası için 18. yüzyıl aydınlanma felsefesinin yayıldığı dönem olarak Aydınlanma Çağı olarak adlandırılmaktadır. Bu dönemde yeni buluşların ve coğrafi keşiflerin etkisiyle sosyal, kültürel ve ekonomik anlamda farklı bir döneme girmiş, sanayileşme sonucu oluşan çok sayıda ticaret kenti Avrupa'yı geçmişe kıyasla hareketlendirmiştir. Bu süreçte, politik ve ticari haberler veren dergiler ilk defa Almanya'da Zeitung, İtalya'da 
Gazetta adı ile yayınlanmıştır (Kürkçüer 1969, 6). Derebeylik geleneğinin yerini orta sınıfın aldığı, sanayi alanında yaşanan gelişmelerle işçi sınıfının doğduğu bu dönemde, hürriyetçilik ve milliyetçilik ideolojileri ve hızlı endüstrileşme Avrupa kıtasının siyasi ortamını hareketlendiren unsurlar olmuşlardır.

Özellikle okuma-yazma oranının düşük olduğu dönemlerde ve toplumlarda, bireylerin alışık olmadıkları bu yeni ekonomik, siyasal ve sosyal sistemi kendi başlarına algılayarak çözümleyebilmeleri için birtakım görsel anlatımlara ihtiyaç duyulmuştur. Çünkü bireylerin ve toplumların, içsel bir dünyayı dişsallaştırma, benliği ve düşünceleri imgelere yansıtma ihtiyacı nefes alma eylemi kadar temel bir eylem olagelmiştir (Burnett 2012, 52). Bireylerin çevrelerini kendi adına gözlemleyen ve böylece kendilerini diğerleri ile karşılaştırmalarına imkân sağlayan ve algılanabilir düzeye indirgeyen araçlara ihtiyaçları vardır. Bu araçlar da medyadır. Bugün bireyler, hangi topluma ait olurlarsa olsunlar, diğerlerini medya aracılığıyla algılamakta ve tanımaktadırlar. Bir başka deyişle gerçek medya aracılığıyla ve medya üzerinden kurgulanmaktadır (Gökçe \& Gökçe 2011, 17).

18. ve 19. yüzyıllarda sanayileşme alanında görülen hız, basın sektöründe de görülmektedir. Batı medyasında günlük ve haftalık haber gazetelerinin yanı sıra yalnızca görsellerin ve illüstrasyonların yer aldığı, haftalık siyaset ve kültür-sanat yayınlarının varlığı ve sayıca çokluğu bilinmektedir. İletişim alanında farkındalık yaratmanın birincil yolu yaratıcı olmaktan geçmektedir ve bu ihtiyacın Sanayi Devrimi ile başlayarak, söz konusu döneme kadar rekabet kaynaklı ve hızlı bir dönüşüm kaydettiği görülmektedir. Bu süreçte, geçmişten günümüze kadar etkisini hiç kaybetmeden sürdüren ve insanları etkilemenin en bilinen yolu olan imge kullanımı yoğun biçimde insan hayatını etkilemiştir. Söz konusu imgelerin büyük ve önemli bir bölümü gazetelerde karşımıza çıkmaktadır ve illüstrasyonlar, karikatürler ve sonrasında fotoğraflar şeklinde gazetelerde yer almışlardır. Zaman içerisinde daha hızlı baskı makineleri, demiryolu sistemleri, posta servisinin gelişimi için yapılan inşaatlar ve bağlantılar, kitap, dergi ve gazetelerin üretimini ve dağıtımını daha etkin hale getirmiş; böylece uluslar günlük olayları her zamankinden daha hızlı okumayı ve bunlara cevap vermeyi başarmıştır.

İllüstrasyon gazetelerinde yerel gazeteciler veya muhabirler olarak ücretlendirilen sanatçılar, gerçekleşmekte olan olayları tasvir ederken, serbest çalışanlar politik karikatürler, alegorik resimler ve hikâye illüstrasyonları yapmak için para almışlardır. Sanat eserinin basılması için, orijinal sanat eseri -genelde kalem ve mürekkeple- basılan baskı bloklarını yaratan ahşap oymacılar tarafından üretilmişlerdir (https,//www.illustrationhistory.org, 2018). Basın dünyas1nın bu ortamında çalışan muhabirler olgusallık ve eğlence ideallerini aynı anda onaylarlarken, çalıştıkları gazeteler ideallerinden birini ya da öbürünü şiddetle öne çıkarmışlar, böylece gazetecilik öykü ideali ve enformasyon ideali modellerine dayanan bir sisteme oturmuştur (Schudson 2011, 208). Bu bağlamda tüm bu illüstrasyon gazetelerinin amacı her yerde olmak ve her konuyla ilgili bilgi vermek olmuştur.

İllüstrasyon gazetelerinin yalnızca görsellerden oluşması ve çok sayıda baskısının olması bazı kesimler tarafından değersiz bulunmasına rağmen gerçekte bu gazetelerin başarısının içeriğindeki görsellere dayandığı söylenebilir. Çünkü bu görsellerin içeriği okuyucuların/izleyicilerin ilgi duydukları olaylar, yerler, şeyler ve kişiler hakkında bilgiye ulaşması açısından oldukça geniş kapsamlıdır ve gazetelerin yöneticileri görüntülerin en geç iki hafta içinde yayınlanmasını sağlayarak son derece uygun bir zamanlama yöntemi belirlemişlerdir. Böylece okuyucular/izleyiciler gün boyunca, uygun fiyata, ülke çapında ya da uzak şehirlerde hatta farklı ülkelerde yaşanan bir felaketin ilk elden bir görünümünü elde edebilmiş, yeni inşa edilmiş bir köprünün ya da çağdaş resimlerin izlenebilmesi için yeni ve heyecan verici bir yol bulmuştur. 1890'lardan itibaren kullanımı yaygınlaşan klişe yöntemi ile haber görsellerinde sıkça karşılaşılan illüstrasyonlar yerini fotoğraflara bırakmış, böylece fotoğraflar hem sanat hem 
de doküman olarak basın dünyasında yerini almıştır.

\section{Kültürel Kodlar Üzerinden Milletlerin Ayrıştırılması: Avrupa Basınından Örnekler}

Okuyucular/izleyiciler sanatsal betimlemeleri yorumlamak istediğinde, gerçek dünyaya ilişkin deneyim ve bilgilerini bu betimlemelere yansıtarak onları çok değişik, deney niteliğindeki yorumlar aracılığıyla sinavdan geçirir (Gombrich 2015, 264). Bir başka deyişle, imgeleri görmek aynı zamanda imgeler ile görmektir (Burnett 2012, 67). Bu bağlamda çalışmaya konu olan etnik milliyetçilik kavramının, gerek Batı dünyasını temsil eden Avrupa ülkeleri gerekse Yakın Doğu dünyasını temsil eden Osmanlı İmparatorluğu'nun merkeze alındığı görsel yansımaları ve imgeleri ile anlamlandırılması söz konusu olmaktadır. İmgeler başlangıçta orada bulunmayan şeyleri gözde canlandırmak amacıyla yapılmıştır. Zamanla imgenin canlandırdığı şeyden daha kalıcı olduğu anlaşılmıştır. Böyle olunca imge bir nesnenin ya da kişinin bir zamanlar nasıl göründüğünü böylece konunun eskiden başkalarınca nasıl göründüğünü de- anlatılmış olur (Berger 1999, 10).

Görsellerin gerçekleme gücü üzerine düşünüldüğünde, imgelerin insanların duygu, düşünce ve algılarında birincil derecede etkili olduğu ancak görsel iletişimde anlatımsal ifade sorunu yaşandığı söylenebilir. Bu nedenle imgeleri okurken, çözümlerken ya da yorumlarken dikkat etmemiz gereken üç göstergebilimsel değişken vardır. Bunlar; kod, altyazı ve bağlamdır. Göstergebilimde kodlar ya da sistemler, toplumsal uzlaşılar üzerinden iletişimin yürütülmesini sağlayan unsurlardır. Bağlam ise kodları içine işlemiş olan kültür, kodları çevreleyen ve anlamını veren evrendir. Görsel metinler üzerinden sunulan 'anlam', metnin sunduğu yeğlenen okuma ile izleyicilerin kültürel yönelimlerinin ürünüdür. Bu nedenle kodlanmıș metin düzeyinde, hem açık içerik hem de 'görünmez', kabullenilmiş anlamlar dikkate alınmalıdır (Stevenson 2008, 135). İmgeler ve imgeleri içinde yer aldıkları görsel ortam incelenirken, onların kültürlerarası geçişlilik özelliğinin de göz önünde bulundurulması gerekmektedir. Çünkü Doğu ve Batı'nın bulundukları yerden birbirleri için 'öteki' olma halleri, imgelerin kültürlerarası yolculugunda onların nasıl anlam kazandığını da ortaya koymaktadır. Osmanlı imgeleri üzerinden yaratılan 'öteki' kavramı üzerine düşünürken, Osmanlı için 'öteki' olan imgelerin de son derece eleştirel bir üslupla, bir tarafı ötekileştirmeyen niteliklerde üretildikleri oldukça açıktır. Çünkü her toplum veya devlet kendisini dünyanın merkezine koyar ve 'ötekileri' genellikle kendisinden aşağı yerlerde görür ve değerlendirir. Bu eğilimin, diğer ülkelerin imajlarını da etkilediği muhakkaktır (Eravcı 2010, 19).

Bu noktada milliyetçilik ideolojisi çerçevesinde şekillenen toplumların kültürel kodlar üzerinden nasıl ayrıştırıldığı ve etnik kimliklerin nasıl ön plana çıkarıldığı görsel örneklerle aktarılmaya çalışılacaktır. Avrupa basınında yer alan görsellerinin niteliği illüstrasyon, karikatür ve fotoğraf olarak farklı1ık göstermektedir. Görsel tasarımlarda öncelik, Batı dünyası siyasetine konu olan ülkelerin haritaya yerleştirilmiş imgelerine verilmiștir. Milletleri niteleyen bu figürlerin kültürel kodları da onların fiziksel görünümleri üzerinden oluşturulmuş; figürlerin yüz ve beden yapıları, giyim tarzları vb. ile sahip oldukları nitelikler üzerinden milli kimlikleri gösterilmiştir.

Dönemin emperyalizm mücadelelerini ve Avrupalı devletler ve çevresindeki diğer devletleri konu alan bu görsellerde Batı siyasetini aktarmak ve uluslararası ilişkilerin temel dinamiklerini ortaya koymak üzere imgeleştirme yapıldığı görülmektedir. Haritalarda ülkeleri temsil eden tüm figürlerin -ayırt edici olması açısından- başlıklar ya da şapkalar kullandığı, bu şapka ve başlıkların birer gösterge olmasının yanı sıra kültürel özellikleri vurgulamaları açısından birer mit olarak kullanıldıkları kabul edilebilir. Tüm milletlere ait tipolojilerin mitleşmiş unsurlar ve kültürel kod sistemleri ile kurgulandığı, böylece Müslüman Osmanlı İmparatorluğu ve Hristiyan Avrupa ile Rusya'nın yalnızca dinî açıdan değil kültürel aidiyet ve milliyetçilik bağlamında da ayrıştırıldığı ortaya çıkmaktadır (Figür 1, 2, 3 ve 4. Bu figürler http://zoom-maps.com (2018) adresinden alınmış olup, ait oldukları yıllarda yayımlandıkları ülke(ler) bugünkü isimlerine karşılık gelecek şekilde parantez içinde verilmiştir). 


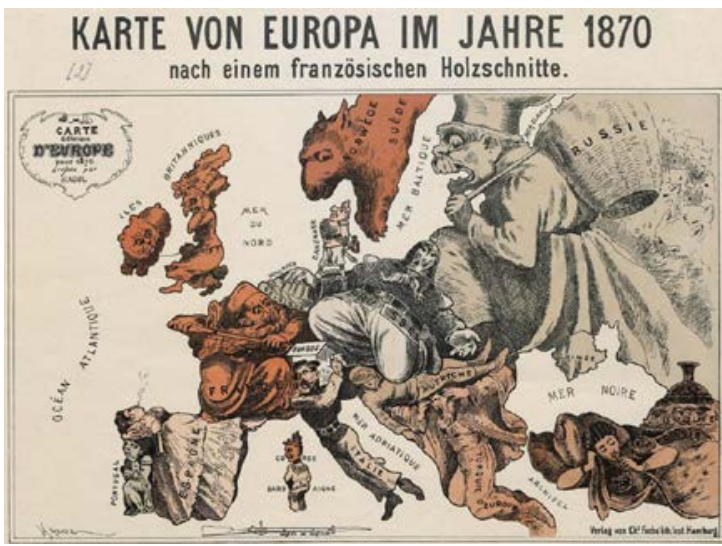

Fig. 1. 1870'de Avrupa Haritas1 (Almanya ve Fransa)

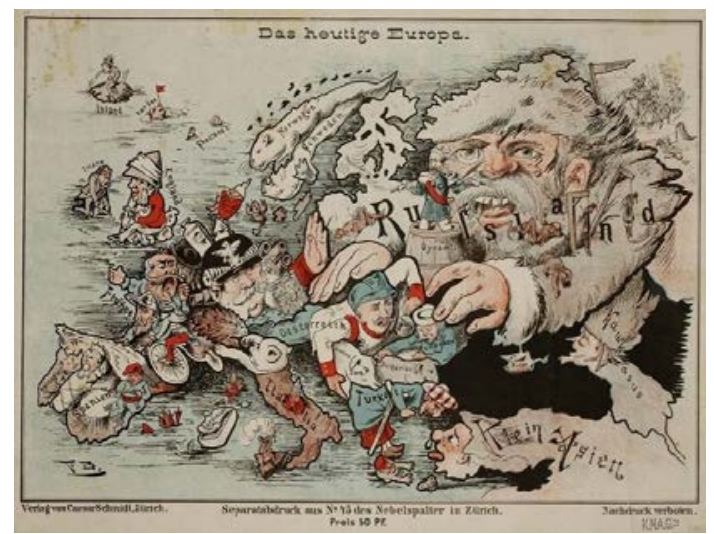

Fig. 3. Bugünkü Avrupa, 1887 (İsviçre)

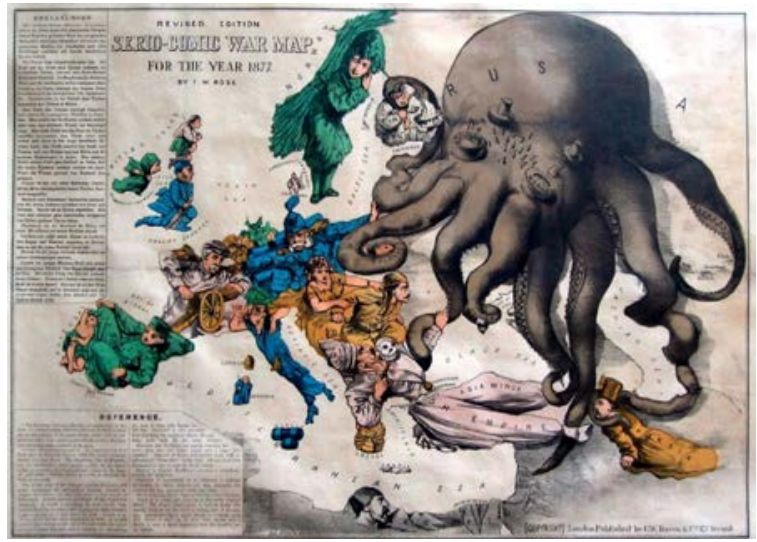

Fig. 2. 1877 Yılının Yarı Şaka Yarı Ciddi Savaş Haritas1 (İngiltere)

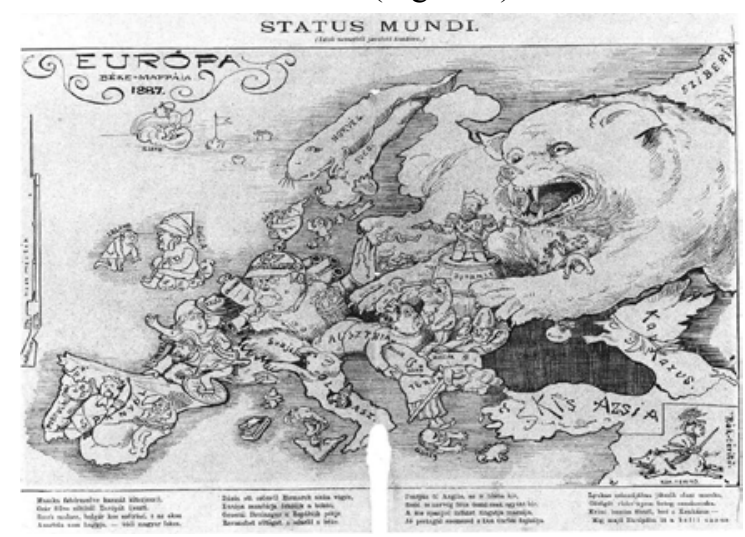

Fig. 4. Dünyanın Gidişatı, 1887 (Macaristan)

Konu itibariyle enformatif özellik taşıyan, farklı milletlere ait tiplemeler hakkında tanıtıcı içeriğe sahip bu görsellerde vurgulanmak istenen ana tema milliyetçiliktir. Ulus devletlerin bağımsızlıklarını ilan ettikleri bir dönemde haber görsellerinde çok sayıda millet ya da etnik kimlik temalı tasarıma yer vermek aynı zamanda onlar için ulus devlet olma yolundaki çabalarına destek olma niteliğindedir. Çok uluslu imparatorlukların dağılması süreci, bünyesinde farklı millet ve etnik kimlikleri barındırmasından ve bu kimliklerin bağımsızlıkları için çıkardıkları ayaklanmalardan kaynaklanmaktadır ve Avrupa basınında bu tip haberlerin sıkça yer almasının yalnızca enformatif amaçlı olmadığ 'ulusal bağımsızlık' ideası olduğu söylenebilir. Milletler ve etnik kimlikler İtalya basınında da tıpkı diğer ülkelerde olduğu gibi siyasi ve askeri konular bağlamında yer almıştır. Bu noktada milliyetçiliğin yanı sıra etnik milliyetçilik ayrıştırmasının, çok uluslu yapıya sahip Osmanlı İmparatorluğu'nun toprak bütünlügünün parçalanması ve dağılması sürecine olan etkisi önemli ve dikkat çekicidir. 1877-1878 Osmanlı-Rus Savaşı'na ait haber görselleri arasında bölge halkının milliyet etnik kimliklerinin ön plana çıkarıldığı görülmektedir (Figür 5, 6 ve 7. Figür 5 ve 6, L'Illustrazione Italiana, 17 Haziran 1877, Y1l: 4, Say1: 24, Sayfa: 381; Figür 7, L'Illustrazione Italiana, 24 Haziran 1877, Y1l: 4, Sayı: 25, Sayfa: 396-397). Benzer biçimde İstanbul şehrinin tanıtıldığı bir haberde kullanılan haber fotoğrafinda da yine milliyetin (Arap) altı çizilmekte ve etnik milliyetçilik vurgusu yapılmaktadır (Figür 8, L'Illustrazione Italiana, 23 Kasim 1890, Y11: 27, Say1: 47, Sayfa: 36). 

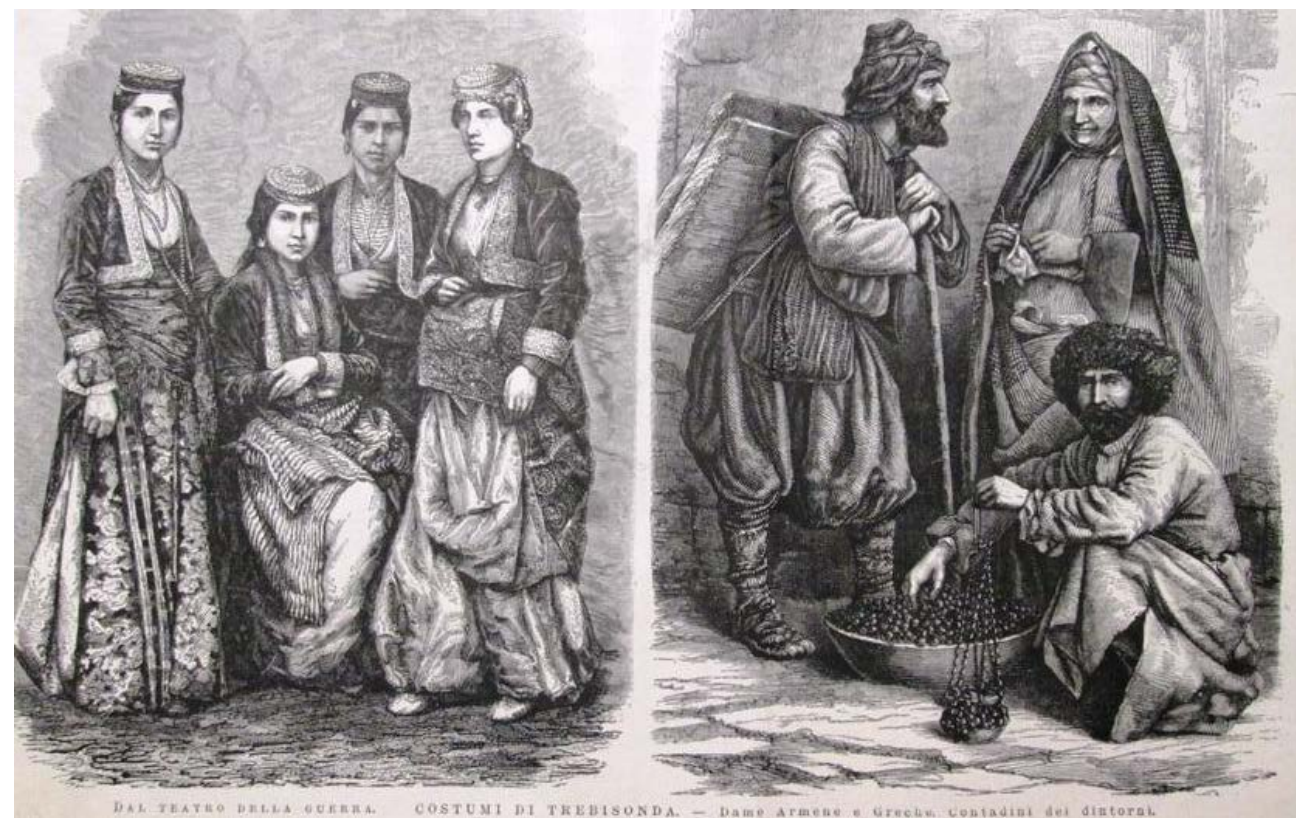

Fig. 5. Trabzon Kostümleri - Ermeni ve Yunan Kadınları - Yerel Çiftçiler (İtalya)

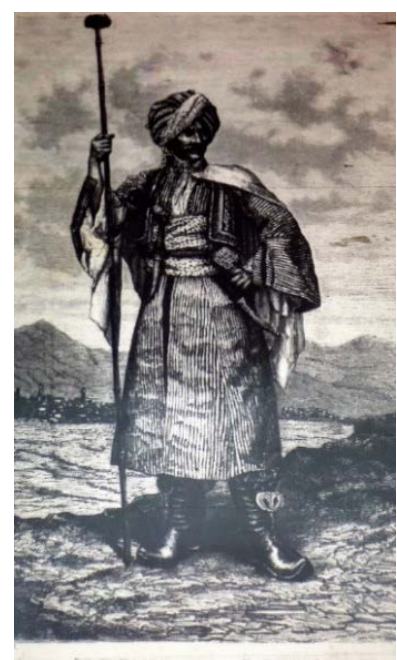

Fig. 6. Kürt Lideri

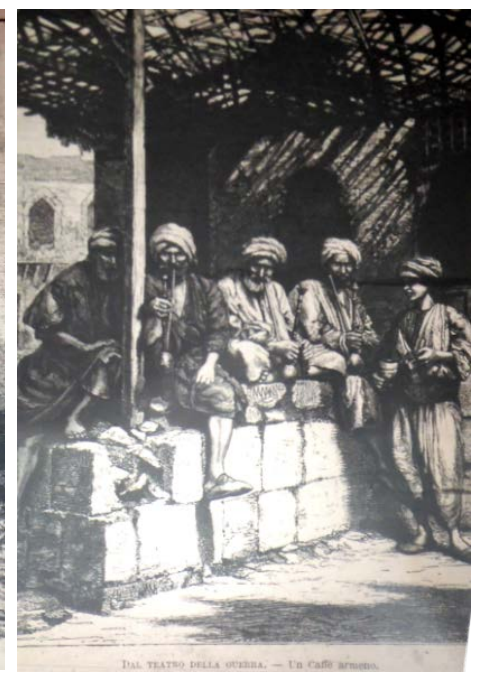

Fig. 7. Ermeni Kahvesi

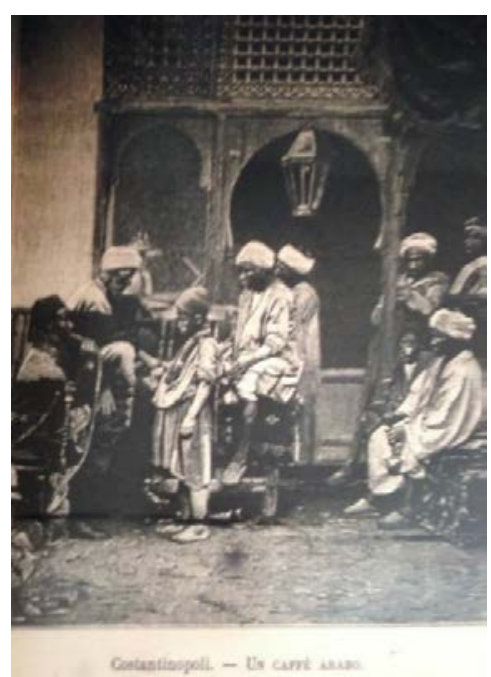

Fig. 8. Arap Kahvesi

Avrupa basınında sıklıkla karşılaşılan görsel metinler arasında Osmanlı imgesi (genellikle Türk, Ermeni, Misırlı, Arap, Balkan halkları ve Kürt olarak milli ya da etnik kimlikleri üzerinden adlandırılmış ve tanımlanmış biçimde) içerikli millet veya etnik kimlikleri tanıtıcı nitelikteki haberler de bulunmaktadır. Bu tarz haberler yalnızca resimli gazeteler olan illüstrasyon gazetelerinde değil, yazılı basın olarak değerlendirilebilecek gazetelere de konu olmuştur. Kendi içinde siyasi, kültürel ve karikatür nitelikli olarak sınıflandırabileceğimiz bu çizimlere sadece ulusal ve yerel gazetelerde değil, çocuklara yönelik masalların ve hikâyelerin yer aldığı yayınlarda dahi rastlamak mümkündür. Gerek siyasi ve askeri konuları ele alan gerekse imparatorluğun günlük yaşam pratiklerini içeren haber içeriklerinde; söz konusu içerikleri görsel olarak da pekiştirmeyi amaçlayan kent görünümlerinin, dinî konuların ve sanat eserleri içerikli haberlerin de Osmanlı İmparatorluğu'ndaki etnik milliyetçilik ayrıştırmasının altını çizen niteliklerde karşımıza çıktığı görülmektedir (Figür 9, 10 ve 11. Figür 9, L'Illustrazione Italiana, 23 Eylül 1877, Y11: 4, Say1: 38, Sayfa: 197; Figür 10, L'Illustrazione Italiana, 3 Aralık 1905, Y11: 32, Say1: 49, Sayfa: 550 ve 553; Figür 11, L'Illustrazione Italiana, 17 Kasim 1895, Y11: 22, Say1: 46, Sayfa: 308 ve 315). 


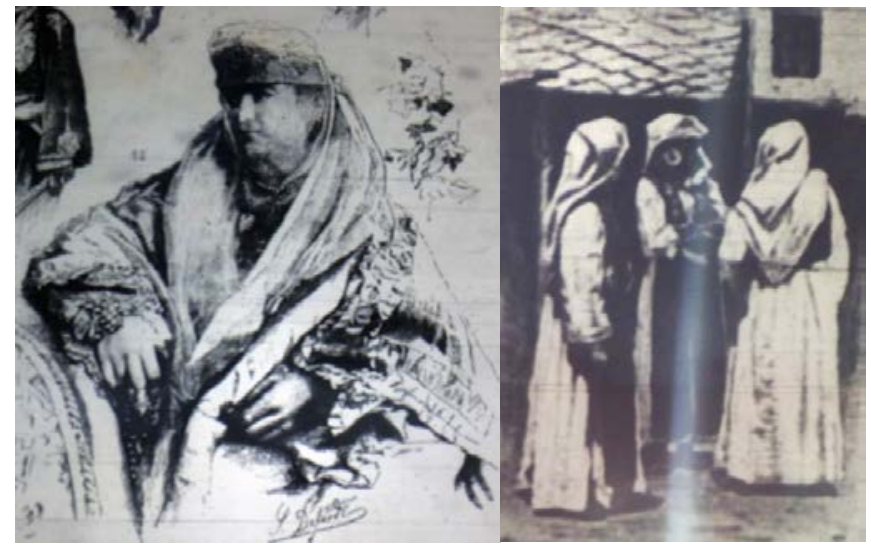

Fig. 9. Çerkez Kadın
Fig. 10. Bosnalı Kadınlar

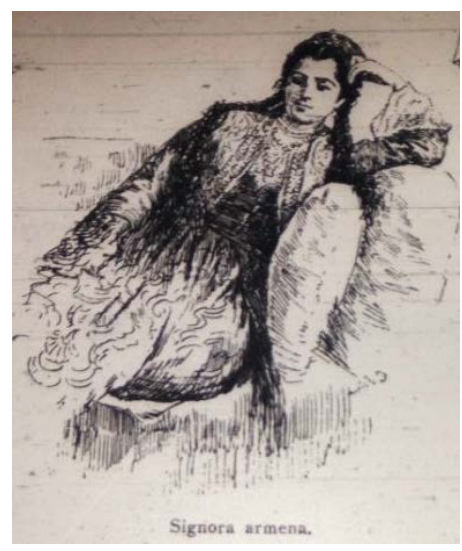

Fig. 11. Ermeni Kadın

Avrupa basınında Türk, Ermeni, Arap, Kürt, Yunan, Bulgar, Arnavut, Karadağl1, Bosnalı, Hırvat, Çerkez, Afrikalı, Lezgi vb. imparatorluk topraklarında ya da denetiminde yaşayan tüm millet ve etnik kimliklere yer verilmiştir. Figürlerin ait oldukları millet ya da etnik kimliğe ait belirgin özelliklerinin ön plana çıkarılarak resmedildikleri görülmektedir. Bu noktada figürlere ait söz edilecek olan tüm fiziksel özellikler, birbirleri ile karşılaştırılarak kültürel kodlar ve tanımlayıcı unsurlar olarak ortaya konmaktadır. Buna göre Türk erkek tiplemeler beyaz tenli, uzuna yakın orta boylu, koyu renk kaş ve gözlüdür ve bir kısmı sakallı olmakla birlikte tamamı mutlaka kalın bıyıklıdır; kadın Türk tiplemeler beyaz tenli, orta boylu ve tombuldur ve Türk kadınları mutlaka örtülüdür ve saçları çok nadir görülmektedir. Balkan coğrafyasının tamamına, Çerkezlere, Bulgarlara ve Yunanlara ait erkek tiplemeler beyaz tenli, uzun boylu ve bir kısmı bıyıklıdır; kadın tiplemeler beyaz tenli, uzun boylu ve incedir ve kadınlar yarı örtülü ya da açıktır. Ermeni tiplemelerinde erkeklerin koyu esmer ten renginde, bıyık ve sakallı, köşeli yüzlü, kaşları ve gözleri birbirine yakın, uzuna yakın orta boylu sayılabilecek ölçüye ve daha kalın vücut hatlarına sahip oldukları görülmektedir. Bu vücut hatlarına benzer fiziksel özellikler Kürt ve Lezgi erkekleri için de geçerlidir. Ermeni kadınlar ise koyu renk saçlıdır ve elbise, şalvar ve cepken gibi açık giysiler içinde tasvir edilmişlerdir. Afrika coğrafyasında yaşayan tiplemeler Misır, Trablus ve Sudan, Etiyopya, Somali gibi yerel yaşamın sürdüğü yerlerden gerçeğe uygun olarak farklı resmedilmiştir (Figür 12, La Rana, 7 Ocak 1887, Y11: 23, Sayı: 1, Sayfa: 2-3).

Misır'da ya da Trablus'ta yaşayan tiplemelerin ve görsellerde yer alan Arap tiplemelerinin imparatorluk yapısına bağlı biçimde yaşadıkları ve Osmanlı imajına benzer oldukları da dikkati çekmektedir. Bu tiplemelerden orta doğu coğrafyasına ve Osmanlı imajına yakın olan erkekler siyahi, kısaya yakın orta boylu, bir kısmı bıyıklı, bir kısmı fes ancak çoğu ilaşu takan figürler olarak karşımıza çıkmaktadır. Kadınlar ise Türk kadınından farklı olarak daha kapalı, peçeli, yalnızca gözleri görünür biçimde, ten rengi çok görünmemekle birlikte siyahi, orta boylu ve Türk kadınına oranla ince yapılıdır. Afrika kıtasında daha yerel bir hayatı olan ve Osmanlı İmparatorluğu denetimi altında bulunan coğrafyalarda yaşayan figürler ise yerel görünüm içinde resmedilmişlerdir. Buradaki coğrafyada yaşayan erkeklerin giysi olarak çok bol kumaşlardan oluşan elbise benzeri giysiler içinde oldukları ya da kumaşlara sarındıkları; bazen üst bedenlerinin çıplak olduğu ve şort boyunda kumaşın büzülmesi ile elde edilen bir alt giyim tercih ettikleri görülmektedir. Erkek figürlerin bazıları Osmanlı imgesine benzer olarak yalnızca fes takmış olarak ve çok az görülen kadın figürler çarşaf benzeri kapalı bir giysi içinde resmedilmişlerdir. Tipolojileri ile ilgili genel bir özetle tasvir edilen bu figürlerin tamamının milletleri, ulusal kimlikleri ya da etnik kökenleri tanıtmaya yönelik yöresel kostümler içinde yer aldığı da görülmektedir. İlk görünüşte enformatif nitelikteki bu figürlerin kültürel kodları da figürlerin 
fiziksel görünümleri özellikleri üzerinden oluşturulmuş; figürlerin yüz ve beden yapısı, fiziksel görünümleri, giyim tarzları, yaşam alanları, ibadethaneleri vb. sahip oldukları nitelikler onların kültürlerini göstermiş, böylelikle çok uluslu olan Osmanlı İmparatorluğu'nda yaşayan tüm millet ve etnik kökene sahip halkların kültürel kodları görsel olarak tanımlanmıştır.

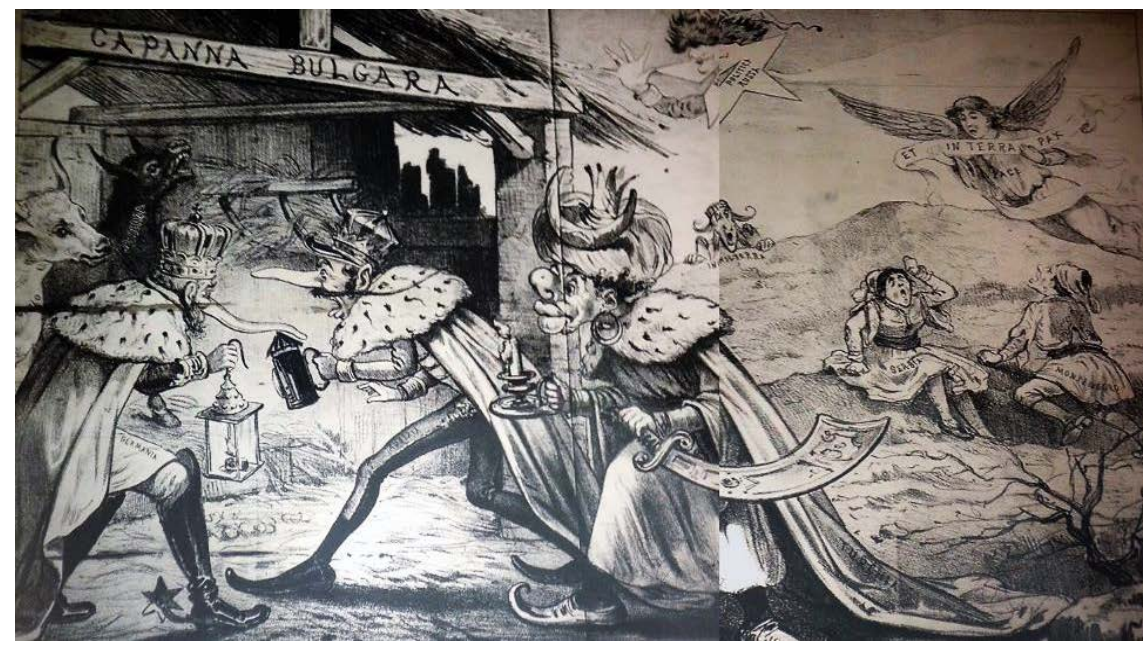

Fig. 12. Müneccimler Hakkında / Bulgar Kulübesi

\section{Sonuç}

Milliyetçilik hareketlerinin Fransa'da bir devrim yaratmasının ardından bu fikirlerin diğer coğrafyalara yayılması ve özellikle imparatorlukları etkileme süreci, dünya tarihini ulus devletlerin güçlendiği bir evreye doğru biçimlendirmiştir. Milliyetçilik akımlarının yayılması öncelikle bünyesinde farklı etnik ve kültürel kimlik barındıran imparatorluklar içinde gerçekleşmiş; her bir grup kendine ait ayrıcalıklar istemiş, alamayınca da kendi kaderini tayin hakkı çerçevesinde ulus devletlerini kurma arayışlarına girmiştir. Bu noktada milletler ve etnik gruplar, kendi kimliklerini ortaya koymak için birçok legal ve illegal girişimlerde bulunmuşlar, bu girişimlerin bir bölümü yalnızca siyasi değil askeri müdahalelere sebep olmuştur. 19. yüzyılın başlarında Yunan halkları, ilerleyen dönemlerde Balkan halkları (Sırp, Arnavut, Karadağlı, Bosnalı, Bulgar vb.) ile Ermeni halkların ayaklanma, isyan ve bağımsızlık girişimleri Osmanlı İmparatorluğu'ndaki etnik milliyetçilik hareketleri olarak özetlenebilir.

Milliyetçilik ideolojisinin milleti tanımlama aşamasında, 19. yüzyılda etkinlik kazanmış olan gazetelerin ve okuma yazma oranının artmasının önemi büyüktür. Bu çerçevede gazetelerin özellikle kullandığı görsellerle etnik ayrımları desteklemesi 'biz' ve 'öteki' bilincini oluşturmada son derece etkilidir. Osmanlı İmparatorluğu da bu fikir akımlarından etkilenmiş, tüm etnik unsurları bir arada tutmak için giriştiği reformlara rağmen parçalanmayı önleyememiştir. Osmanlı İmparatorluğu'nda milletler sisteminin öznesi konumundaki gayrimüslimlerin bilinçlenmesinde, Avrupa basınının bu yöndeki çabaları büyük ölçüde belirleyici ve yönlendirici olmuş ve kültürel kodları ayrıştırarak milliyetçilik akımlarının güçlenmesini sağlamıştır.

Haber görselleri olmaları açısından enformatif nitelikteki söz konusu imgeler, farklı millet ya da etnik kökenlere işaret ederek Osmanlı İmparatorluğu'nun çok uluslu yapısını vurgulamaktadır. 19. yüzyıl ortalarında hepsi birbirinden farklı olan bu gayrimüslim topluluklar hem topraksal hem de yönetim usulüne yönelik itirazlarıyla milliyetçi tartışmaların artmasına sebep olmuşlardır. Ancak haber içeriklerindeki görsellerin yalnızca isyan eden ya da ayaklanan millet ya da etnik kimliklere sınırlı olmadığı, siyasi ya da askeri konulu haberlerin yanı sıra imparatorluğun başkenti İstanbul'un tanıtıldığ 1 haberlerde dahi milliyet ve etnik kimliklere yer verildiği görülmektedir. Ulusal kimlik tanımlama ideası çerçevesinde söz konusu görsel metinlerin hem 
ait olunan millet ya da etnik köken hem de din ve inanç sistemleri üzerinden oluşturulduğu, çatışan tarafların milliyet ve dinleri üzerinden tasvir edilmesiyle bir kez daha ortaya çıkmaktadır. Osmanlı halkının sosyal yapısının ortaya konduğu tasarımlarda, milletlerin ve etnik kökenlerin ayr1 ayrı ortaya konması, dönemin milliyetçilik ideolojisi ve ulus-devlet kurma ideaları çerçevesinde manipülasyona sebep olmakla birlikte, imparatorluğun çok uluslu yapısına ayna tutması açısından enformatiftir. Sonuç olarak Avrupa basınında yer alan görsel metinlerde yer alan kültürel kodların ve kamuoyuna sunulan söz konusu milli ya da etnik kimlikle tanımlanmış imgelerin, kültürel bir nesne olarak 'öteki' olma halinin ön plana çıkarılarak etnik milliyetçilik ayrıştırması yapan birer gösterge oldukları bulgularına ulaşılmıştır.

Yazarların Notu: Bu çalışma 2. yazarın 'İtalya Basınında Sultan II. Abdülhamid Dönemi Osmanlı İmgesi' adlı doktora tezinden görseller ve bölümler içermektedir (Hacettepe Üniversitesi Sosyal Bilimler Enstitüsü, 2018). 


\section{KAYNAKÇA}

Aktar C. (2003). "Osmanlı Kozmopolitizminden Avrupa Kozmopolitizmine Giden Yolda Ulus Parantezi”.

Türkiye'de Siyasal Düşünce 4 (2003) 77-80. İstanbul.

Amin S. (2007). Avrupamerkezcilik, Bir İdeolojinin Eleştirisi, Çivi Yazıları. İstanbul 2007.

Anderson B. (2011). Hayali Cemaatler, Milliyetçiliğin Kökenleri ve Yayılması. İstanbul 2011.

Armaoğlu F. H. (1973). Siyasi Tarih 1789-1960. Ankara 1973.

Belge B. (1939). "Modern Turkey”. International Affairs (Royal Institute of International Affairs 19311939) 18/6 (1939) 745-762.

Berger J. (1999). Görme Biçimleri. İstanbul 1999.

Breuer S. (2010). Milliyetçilikler ve Faşizmler: Fransa, Italya ve Almanya Örnekleri. İstanbul 2010.

Burnett R. (2012). İmgeler Nasll Düşünür?. İstanbul 2012.

Calhoun C. (2012). Milliyetçilik. İstanbul 2012.

Cezar M. (1971). Sanatta Batı'ya Açılış ve Osman Hamdi. İstanbul 1971.

Çiller Y. (2015). "Modern Milliyetçilik Kuramları Açısından 19. Yüzyıl Osmanlı İmparatorluğu Fikir Akımları". Akademik Incelemeler Dergisi 10/2 (2015) 45-65.

Eravcı H. M. (2010). Avrupa'da Türk Imaji. Konya 2010.

Eriksen T. H. (2002). Etnisite ve Milliyetçilik. Antropolojik Bir Bakış. İstanbul 2002.

Eryılmaz B. (1990). Osmanlı Devleti'nde Gayri-müslim Teb'anın Yönetimi. İstanbul 1990.

Gellner E. (1983). Nations and Nationalism. Oxford 1983.

Gombrich E. H. (2015). Sanat ve Yanılsama. İstanbul 2015.

Göçek F. M. (2003). "Osmanlı Devleti’nde Türk Milliyetçiliğinin Oluşumu: Sosyolojik Bir Yaklaşım”. Modern Türkiye'de Siyasi Düşünce 4 (2003) 64-76. İstanbul.

Gökçe G. \& Gökçe O. (2011). Avrupa'da İslam ve Türk Imajı. Ankara 2011.

Güler A. (2000). Osmanlıdan Cumhuriyete Azınlıklar. Ankara 2000.

Halperin S. (2003). War and Social Change in Modern Europe, The Great Transformation Revisited. USA 2003.

Hobsbawm E. (1993). Milletler ve Milliyetçilik. İstanbul 1993.

Karpat K. (2014). Osmanlı'dan Günümüze Kimlik ve İdeoloji. İstanbul 2014.

Kedourie E. (1994). Nationalism. Oxford 1994.

Kerestecioğlu İ. (2012). "Milliyetçilik: Uyuyan Güzeli Uyandıran Prens”ten Frankenştayn'ın Canavarına". Ed. H. Birsen Örs, 19. Yüzylldan 20. Yüzylla Modern Siyasal İdeolojiler (2012) 307-350. İstanbul.

Kürkçüer O. M. (1969). Siyasi Tarih. Ankara 1969.

Le Goff J. (1997). Gençlere Avrupa Tarihi. İstanbul 1997.

Mardin Ş. (1994). Türk Modernleşmesi. İstanbul 1994.

Özkırımlı U. (2010). Milliyetçilik Üzerine Güncel Tartısmalar, Elesştirel Bir Müdahale. İstanbul 2010.

Özkırımlı U. (2013). Milliyetçilik Kuramları, Eleştirel Bir Baklş. İstanbul 2013.

Sander O. (2003). Siyasi Tarih, İlk Çağlardan 1918'e. Ankara 2003.

Schmidt J. (1992). Through the Legation Window 1876-1926. Leiden 1992.

Schudson M. (2011). "Yeni Gazetecilik”. Yay. Haz. D. Crowley \& Paul Heyer, Illetişim Tarihi (2011) 208217. Ankara.

Shaw S. J. \& Shaw E. K. (1977). History of the Ottoman Empire and Modern Turkey. Volume II. Reform, Revolution and Republic: The Rise of Modern Turkey, 1808-1985. USA 1977.

Smith A. (2013). Milliyetçilik: Kuram, İdeoloji, Tarih. Ankara 2013.

Stevenson N. (2008). Medya Kültürleri, Sosyal Teori ve Kitle Iletişimi. Ankara 2008.

Suny R. G. (2001). "Constructing Primordialism: Old Histories for New Nations”. The Journal of Modern History (2001) 73-4.

Uçar F. (2018). "Türk Düşüncesinde Osmanlıcılık Fikrinin Ortaya Çıkışı ve Türk Siyasal Hayatına Etkileri”. Karadeniz Sosyal Bilimler Dergisi 10/10/18 (2018) 81-108.

https://www.illustrationhistory.org/history/time-periods/late-19th-century (01.03.2018)

http://zoom-maps.com/page/europe-satirical-maps (03.01.2019) 
